Vol. 15 (2006): 200-218.

\title{
Effects of restriction of silage fermentation with formic acid on milk production
}

\author{
Seija Jaakkola \\ Department of Animal Science, PO Box 28, FI-00014 University of Helsinki, Finland, \\ e-mail: seija.jaakkola@helsinki.fi \\ Marketta Rinne, Terttu Heikkilä, Vesa Toivonen, Pekka Huhtanen \\ MTT Agrifood Research Finland, Animal Production Research, FI-31600 Jokioinen, Finland
}

\begin{abstract}
The study was conducted to evaluate the effects of silage fermentation quality and type of supplementation on milk production. Thirty two Finnish Ayrshire dairy cows were used in a cyclic change-over experiment with four 21-day experimental periods and $4 \times 2 \times 2$ factorial arrangement of treatments. Silage fermentation was modified with formic acid (FA), which was applied at the rates equivalent to $0\left(\mathrm{FA}_{0}\right), 2\left(\mathrm{FA}_{2}\right)$, $4\left(\mathrm{FA}_{4}\right)$ or $6\left(\mathrm{FA}_{6}\right)$ litres $\mathrm{t}^{-1}$ grass of pure formic acid (as 100\% FA). Dietary treatments consisted of four silages, a protein supplementation (no supplement or rapeseed meal $1.8 \mathrm{~kg} \mathrm{~d}^{-1}$ ) and a glucogenic substrate (no supplement or propylene glycol $225 \mathrm{~g} \mathrm{~d}^{-1}$ ). Increasing the application rate of FA restricted silage fermentation curvilinearly, as evidenced by higher concentrations of ammonia $\mathrm{N}$ and butyric acid in $\mathrm{FA}_{4}$ than $\mathrm{FA}_{2}$ silage. Similarly the use of FA resulted in curvilinear changes in the silage dry matter intake and milk yield. The highest milk and protein yields were achieved with $\mathrm{FA}_{6}$, while the milk yield with $\mathrm{FA}_{2}$ was higher than with $\mathrm{FA}_{4}$. Interactions were observed between silage type and supplementation. Rapeseed meal increased milk yield irrespective of the extent of silage fermentation, but the magnitude of response was variable. Propylene glycol was most beneficial with restrictively fermented silages $\mathrm{FA}_{4}$ and $\mathrm{FA}_{6}$. In conclusion, restriction of silage fermentation with a high rate of formic acid is beneficial in milk production. Interactions between silage composition and concentrate types suggest that the responses to supplementary feeding depend on silage fermentation characteristics.
\end{abstract}

Key words: grass silage, fermentation, formic acid, dairy cows, milk production

\section{Introduction}

The effects of additives on silage fermentation and consequently on silage intake and animal perform- ance depend on the additive used, its rate of application, the activity of biological preparations, type of forage, dry matter concentration, and chemical composition (Harrison et al. 2003). High application rate $\left(4 \mathrm{t} \mathrm{t}^{-1}\right.$ or higher) of formic acid (FA) re- 
Vol. 15 (2006): 200-218.

stricts silage fermentation resulting in lower concentration of fermentation acids and ammonia $\mathrm{N}$, and higher concentration of residual sugars in silage as compared with extensively fermented untreated or inoculated silage (Chamberlain et al. 1992, Heikkilä et al. 1998, Shingfield et al. 2002a). With lower application rates the differences in fermentation profiles are generally smaller (Gordon 1989, Mayne 1990). In Finland, a relatively high application rate of FA (approximately $4 \mathrm{l} \mathrm{t}^{-1}$, expressed as $100 \% \mathrm{w} / \mathrm{w}$ ) is commonly used in grass preservation.

The effect of FA on silage intake and animal performance is positive especially when compared to relatively poorly preserved untreated silage (Harrison et al. 1994, Kung et al. 2003). The effect of FA treatment on silage intake is mediated through effects on silage fermentation as silage intake is greatly influenced by the fermentation quality of silage (Huhtanen et al. 2002). In addition to intake, additive treatment may modify the nutrient supply to animal through rumen fermentation. Increasing the rate of FA increased microbial protein synthesis in the rumen and microbial $\mathrm{N}$ flow at the duodenum (Jaakkola et al. 2006). On the other hand, restrictively fermented silages favour a high-butyrate and acetate and low-propionate volatile fatty acids (VFA) pattern in the rumen (Martin et al. 1994, Huhtanen et al. 1997, Jaakkola et al. 2006). The low molar proportions of glucogenic relative to lipogenic VFA suggests that glucose may limit milk production with restrictively fermented silages, and indicates a greater dependence on absorbed amino acids for gluconeogenesis. This may lead to increased use of amino acids for glucose production in the liver (Huhtanen 1998). Limited nutrient supply may in some cases explain the lower than expected milk yield responses to FA-treated silage. Therefore, supplementation of restrictively fermented silage with glucogenic substrate may overcome limitations in glucose supply and further improve the utilization of amino acids in milk production.

For optimal supplementation with concentrates and other feeds it is important to quantify the effects of silage fermentation on milk production.
Limited data is available on the systematic effects of increasing FA application rate on the fermentation pattern of silage made using the same sward, and consequently on silage intake and milk production. The aim of the present experiment was to study how the pattern of silage fermentation, when regulated by the application rate of FA, affects silage intake and milk production. Further, the study was conducted to establish whether the effects of silage fermentation on nutrient supply and animal performance could be compensated by supplements of amino acids substrate (rapeseed meal), glucogenic substrate (propylene glycol) or both. Preliminary results have been reported earlier (Jaakkola et al. 1996).

\section{Material and methods}

\section{Silages}

Four experimental silages were made on the experimental farm of MTT Agrifood Research Finland, Jokioinen Estates in Jokioinen, Finland $\left(60^{\circ} 49^{\prime} \mathrm{N}, 23^{\circ} 28^{\prime} \mathrm{E}\right)$. A secondary growth of a mixed timothy (Phleum pratense) - meadow fescue (Festuca pratensis) sward was harvested on 23-24 August using a direct-cut flail forage harvester (Taarup 1500, Kerteminde, Denmark). The sward was previously fertilized for the second cut with 88-14-29 kg N-P-K per hectare, respectively. The grass was treated with formic acid $\left(850 \mathrm{~g} \mathrm{~kg}^{-1}\right)$ which was applied at the rates equivalent to 0 $\left(\mathrm{FA}_{0}\right), 2\left(\mathrm{FA}_{2}\right), 4\left(\mathrm{FA}_{4}\right)$ or $6\left(\mathrm{FA}_{6}\right)$ litres $\mathrm{t}^{-1}$ grass of pure formic acid (as $100 \% \mathrm{FA}$ ). The additives were applied using a pump applicator (Ylö HP-20, Ylöjärvi, Finland) attached to the forage harvester. The target rates were well achieved, since the true rates were 2.2, 4.3 and $6.31 \mathrm{t}^{-1}$ grass. Silages were prepared simultaneously in four concrete-lined bunker silos, each of 80-tonne capacity. Silos were covered with plastic sheets, weighted with a layer of sawdust and opened after six months ensiling period. 
Jaakkola, S. et al. Restriction of silage fermentation with formic acid

\section{Experimental design and diets}

A cyclic change over-design experiment (Davis and Hall 1969) with 32 Finnish Ayrshire cows (including six primiparous) in two blocks and with 16 dietary treatments was conducted. Cows were assigned to two experimental blocks according to milk yield and allocated at random to experimental treatments. Dietary treatments in a $4 \times 2 \times 2$ factorial arrangement consisted of four silages $\left(\mathrm{FA}_{0}\right.$, $\mathrm{FA}_{2}, \mathrm{FA}_{4}$ and $\mathrm{FA}_{6}$ ), a protein supplementation (no supplement (-RSM) and rapeseed meal (+RSM)) and a supplement of propylene glycol (-PG and $+\mathrm{PG})$. The study consisted of four 21-day experimental periods with adaptation period from day 1 to 13 followed by a sampling period from day 14 to 21 .

The cows had a mean (SD) live weight of 567 $\mathrm{kg}$ (59.8), a parity of 3.1 (1.61) and were 52 days (17.1) in lactation, producing $34.9 \mathrm{~kg}$ (5.00) milk per day. They were housed in individual stalls. The cows had free access to silage allowing 5 to $10 \%$ refusals. The basal concentrate mixture was formulated from barley and oats coarsely ground by a hammer mill, dry molassed sugar beet pulp (SBP) and mineral and vitamin supplement $(\mathrm{Ca}$ 165, P 72, Na 80, Mg $80 \mathrm{~g} \mathrm{~kg}^{-1}$, Cu 500, Se 10, Zn 3000, Mo 8, Co 12, Mn 980, I $100 \mathrm{mg} \mathrm{kg}^{-1}$, A vitamin 150000 , D vitamin $60000 \mathrm{KY} \mathrm{kg}^{-1}$, and $\mathrm{E}$ vitamin $400 \mathrm{mg} \mathrm{kg}^{-1}$; Viher-Minera Muro, Suomen Rehu Ltd, Helsinki, Finland). The composition of the basal mixture was modified to increase the supply of amino acids or glucose or both resulting in four different mixtures (Table 1). In protein-sup- plemented diets RSM (Raisio Feed Ltd, Raisio, Finland) replaced $200 \mathrm{~g} \mathrm{~kg}^{-1}$ of cereals in the basal mixture and in PG diets animals were given 250 or $200 \mathrm{~g} \mathrm{day}^{-1}$ of propylene glycol included in the SBP in blocks 1 and 2, respectively. Since PG did not replace the basal mixture the daily concentrate portion was $0.25 \mathrm{~kg}$ higher for PG diets. Sugar beet pulp and SBP including PG were prepared by a feed factory (Lännen Tehtaat PLC, Säkylä, Finland). Concentrate was offered at 10.00 or 10.25 (block 1) and 8.00 or 8.25 (block 2) kg per day for diets $-\mathrm{PG}$ and $+\mathrm{PG}$, respectively. Daily concentrates were offered as three equal meals at 0530 , 1230 and 1630.

\section{Experimental procedures}

Samples of ensiled grass were collected from every load at the time of ensiling and immediately stored at $4^{\circ} \mathrm{C}$. Once ensiling was completed, samples were submitted for the determination of dry matter (DM), ash, neutral detergent fibre (NDF), acid detergent fibre (ADF), total nitrogen $(\mathrm{N})$, soluble $\mathrm{N}$ and water soluble carbohydrates (WSC). During the sampling period of animal experiment, representative samples of silages and concentrates were collected daily. Concentrates were analysed for DM, ash, NDF, ADF, N and acid insoluble ash (AIA). Silages were analysed for DM, ash, NDF, ADF, lignin, N, AIA, in vitro organic matter digestibility, $\mathrm{pH}$, lactic acid, VFA, ethanol, WSC and ammonia and soluble N. Silage samples and DM concentration of concentrate were analysed sepa-

Table 1. Composition of the experimental concentrates $\left(\mathrm{g} \mathrm{kg}^{-1}\right)$.

\begin{tabular}{lcccc}
\hline & Basic & $\begin{array}{c}\text { Basic }+ \\
\text { Rapeseed meal }\end{array}$ & $\begin{array}{c}\text { Basic }+ \\
\text { Propylene glycol }\end{array}$ & $\begin{array}{c}\text { Basic + Rapeseed meal } \\
\text { + Propylene glycol }\end{array}$ \\
\hline Barley & 395 & 295 & 385.4 & 287.8 \\
Oats & 395 & 295 & 385.4 & 287.8 \\
Rapeseed meal & & 200 & & 195.1 \\
Molassed sugarbeet pulp & 175 & 175 & 170.7 & 170.7 \\
Propylene glycol & & & 24.4 & 24.4 \\
Mineral mixture & 35 & 35 & 34.1 & 34.1 \\
\hline
\end{tabular}


Vol. 15 (2006): 200-218.

rately for each period. For the determination of chemical composition, concentrate samples were pooled over two periods resulting in two separate determinations.

Feed intake and milk yield were recorded daily. Cows were milked twice daily at 0630 and 1530 . Milk samples were obtained from four consecutive milkings on day 18 to 20 and analysed by infra-red milk analyser (Milko-Scan 133B, Foss Electric, Hillerød, Denmark) for fat, protein and lactose. A separate single milk sample from an evening milking on day 20 was taken for urea determination. Cows were weighed on two consecutive days at the beginning of the experiment and on days 20 and 21 of each experimental period at 1000 .

Whole tract apparent digestibility was estimated using AIA as an internal marker (Van Keulen and Young 1977). During the last 5 days of each period spot faecal samples were collected at 0630 and 1530 from 16 cows assigned to block 1 . At the end of each period, samples were pooled on an individual cow basis, thoroughly mixed, subsampled and stored at $-20^{\circ} \mathrm{C}$.

Blood samples from all experimental animals were collected on day 20 of each period at 1230 and 1630. Samples were taken from the coccygeal vessels by venipuncture into evacuated collection tubes (Venoject, Terumo Europe Ltd., Leuven, Belgium) containing potassium ethylene diamine tetra-acetic acid (EDTA) and placed on ice. Once collected, blood samples were centrifuged (15 min at $900 \mathrm{~g}$ at $4^{\circ} \mathrm{C}$ ), and the plasma supernatant assigned for beta-hydroxy-butyrate $(\beta-\mathrm{OHB})$ and urea determinations was stored at $-80^{\circ} \mathrm{C}$. Glucose and non-esterfied fatty acid (NEFA) concentrations were determined immediately. For NEFA determination only the sample at 1230 was used.

The metabolisable energy (ME) concentration of the diets was calculated in two ways. The first approach was based on estimating silage ME concentration $\left(\mathrm{MJ} \mathrm{kg}^{-1} \mathrm{DM}\right)$ as $0.016 \times$ in vitro digestible organic matter in the dry matter $\left(\mathrm{g} \mathrm{kg}^{-1} \mathrm{DM}\right)$ (DOMD) (MAFF 1975) and that of concentrate using published digestibility coefficients (MTT 2006) for each ingredient. The second approach was based on predicting ME intake from digestible organic matter $(\mathrm{OM})$ measured in cows assuming a
ME concentration of $16 \mathrm{MJ} \mathrm{kg}^{-1}$ digestible $\mathrm{OM}$ (MAFF 1975). Measurements of AIA apparent OM digestibility coefficients determined for each cow were used for animals in block 1 , while mean values for each dietary treatment found for block 1 were used for animals in block 2 . In both cases, PG (gross energy concentration $20.8 \mathrm{MJ} \mathrm{kg}^{-1} \mathrm{DM}$; McDonald et al. 1995) was assumed to be completely digested with no methane production. Estimates of ME intake based on tabulated values and on measured $\mathrm{OM}$ digestibility are subsequently referred to as $\mathrm{ME}_{\mathrm{TAB}}$ and $\mathrm{ME}_{\mathrm{DET}}$, respectively. Milk energy concentration was estimated according to Sjaunja et al. (1990) and ME requirement for maintenance according to MAFF (1984). The efficiency of utilization of ME for milk production was calculated ignoring changes in live weight.

Protein balance in the rumen (PBV) and amino acids absorbed in the small intestine (AAT) were calculated according to a modified Nordic AATPBV protein evaluation system adopted in Finland (MTT 2006). Forage AAT and PBV concentration was calculated using the equations based on crude protein concentration and measured DOMD (MTT 2006). Concentrate AAT and PBV concentrations were calculated using published values for individual concentrate ingredients (MTT 2006). Estimates of the efficiency of utilization of AAT for milk protein synthesis and milk production were calculated ignoring changes in live weight.

Rumen fermentation was studied simultaneously with the dairy experiment with four rumen fistulated cows in a $4 \times 4$ Latin square experiment. The cows had a mean daily DM intake of $16.3 \mathrm{~kg}$ and mean milk yield of $13.1 \mathrm{~kg}$. Dietary treatments consisted of four silages $\left(\mathrm{FA}_{0}, \mathrm{FA}_{2}, \mathrm{FA}_{4}\right.$ and $\left.\mathrm{FA}_{6}\right)$ offered ad libitum. In addition, the cows were offered one of the concentrate mixtures (+RSM, $-\mathrm{PG}$ ) at $5 \mathrm{~kg}$ per day. The study consisted of four 21-day experimental periods. Feed intake, milk yield and milk composition were measured as in the dairy experiment.

To assess ruminal fermentation, samples were obtained via the rumen cannula using a vacuum pump on day 19 of each period immediately before the meal at 1230 and 1.5, 3.0, 4.5, 6.0, 7.5 and 9.0 hours thereafter. Immediately after removal, $\mathrm{pH}$ 
Jaakkola, S. et al. Restriction of silage fermentation with formic acid

was measured and the samples were filtered through two layers of cheesecloth. Samples of rumen fluid destined for VFA determinations were immediately preserved with $0.5 \mathrm{ml}$ of saturated mercury (II) chloride and $2.0 \mathrm{ml}$ of $1 \mathrm{M}$ sodium hydroxide and stored at $-20^{\circ} \mathrm{C}$. Samples of rumen fluid submitted for ammonia determinations were immediately preserved with $0.3 \mathrm{ml}$ of $50 \%(\mathrm{v} / \mathrm{v})$ sulphuric acid and stored at $-20^{\circ} \mathrm{C}$. To count rumen protozoa, samples were pooled to provide one sample per day, and stored in formalin.

\section{Analyses}

Chemical analyses of the feed and faecal samples, and milk urea measurement were made as reported previously by Huhtanen and Heikkilä (1996). Total $\mathrm{N}$ and soluble $\mathrm{N}$ concentrations in fresh silage samples were measured by the Kjeldahl method using $\mathrm{Cu}$ as a digestion catalyst and Tecator 1028 Distilling Unit. Silage ethanol concentration was determined according to Huida (1982). A modification of the method described by Nousiainen et al. (2003) was used to measure in vitro OM digestibility of the forages. The results were calculated with a correction equation to convert pepsin-cellulase solubility values into in vivo digestibility by an equation based on a data set comprising of Finnish in vivo digestibility trials. Blood glucose, NEFA, urea and B-OHB were analysed as reported by Rinne et al. (1999). Rumen volatile fatty acid and ammonia $\mathrm{N}$ concentrations were determined as explained by Shingfield et al. (2001). The protozoa in the rumen fluid were counted using a haemocytometer after fixing the samples with a methyl green-formalin solution.

\section{Statistical analysis}

Measurements collected during the sampling period were used when calculating the feed intake and milk production results. Three observations were lost due to health problems not related to the experimental diets. Experimental data was subjected to Analysis of Variance using the General Linear
Model procedure (PROC GLM) of Statistical Analysis Systems Institute (SAS $\left.{ }^{\circ}, 1989\right)$ ). The statistical model included the effects of block, cow within block, period and treatment. Treatment carry-over effect was included for milk production and feed consumption data, but no significant effects were found. For blood metabolite data, the results were analysed by a split-plot analysis of variance with sampling time as a sub-plot (Snedecor and Cochran 1967).

Sums of squares for treatment effects were further separated using orthogonal contrasts into single degree of freedom comparisons for the linear, quadratic and cubic effect of the FA rate and the effects of RSM and PG supplementation. Further contrasts were performed to assess the significance of interactions between the main treatment effects. Results are presented for the main effects of linear (L), quadratic (Q) and cubic (C) effects of FA rate, and RSM and PG supplementation. The probabilities of the statistical significances of FA rate are expressed by $\mathrm{P}_{\mathrm{L}}, \mathrm{P}_{\mathrm{Q}}$, and $\mathrm{P}_{\mathrm{C}}$. The results of the main treatment effects are presented in the Tables while the milk production results for all 16 treatments are shown in Figures due to the observed interactions.

Rumen fermentation data was analysed using the same split-plot analysis as for blood metabolites. The effects due to block were removed and treatment effects were separated into L, Q and C effects of FA application rate.

\section{Results}

The chemical composition of the grass ensiled, and the silages are shown in Table 2 and that of the concentrates in Table 3. Grass had a high WSC (129 $\left.\mathrm{g} \mathrm{kg}^{-1} \mathrm{DM}\right)$ and moderate crude protein concentration (145 $\left.\mathrm{g} \mathrm{kg}^{-1} \mathrm{DM}\right)$. For unwilted material, the DM concentration of grass was relatively high $\left(267 \mathrm{~g} \mathrm{~kg}^{-1}\right)$. Formic acid reduced both respiration and proteolysis after the application, since WSC concentration was higher and soluble $\mathrm{N}$ concentration was lower in FA than untreated grass samples collected at the time of filling the silos. 
Vol. 15 (2006): 200-218.

All silages were well preserved although the extent of fermentation was greater in untreated than FA-treated silages. Silage $\mathrm{pH}$ increased from 4.18 to 4.30 when the application rate of FA increased from 2 to $61 \mathrm{t}^{-1}$ while in $\mathrm{FA}_{0}$ silage the $\mathrm{pH}$ value was the same as in $\mathrm{FA}_{6}$. Lactic acid concentration decreased and consequently that of WSC increased with the increasing application rate of FA. The change was not linear as the difference between $\mathrm{FA}_{2}$ and $\mathrm{FA}_{4}$ was relatively small. A slightly higher concentration of butyric and other fermentation acids were observed in untreated silage compared with FA-treated silages. Proteolysis was restricted by the FA treatment indicated by a decrease from 84 to $43 \mathrm{~g}$ ammonia- $\mathrm{N}$ in $\mathrm{kg}$ total
$\mathrm{N}$, when the application rate of FA increased from 0 to $61 \mathrm{t}^{-1}$. Further, FA was effective in reducing the proportion of soluble N. However, the effect was not linear, since $\mathrm{FA}_{4}$ had higher ammonia $\mathrm{N}$ proportion than $\mathrm{FA}_{2}$ silage (60 vs. $51 \mathrm{~g} \mathrm{~kg}^{-1}$ total N).

The use of FA resulted in a curvilinear change $\left(\mathrm{P}_{\mathrm{L}}, \mathrm{P}_{\mathrm{C}}<0.05\right)$ in silage $\mathrm{DM}$ intake the mean response being $+0.15,-0.15$ and $+0.57 \mathrm{~kg} \mathrm{day}^{-1}$ for $\mathrm{FA}_{2}, \mathrm{FA}_{4}$ and $\mathrm{FA}_{6}$ diets, respectively (Table 4). The changes in silage intakes were reflected in total $\mathrm{DM}$ intake $\left(\mathrm{P}_{\mathrm{C}}<0.05\right)$, and nutrient and ME intakes. Dietary RSM supplementation resulted in significant increases in silage and total DM intake $\left(\right.$ mean $\left.+0.49 \mathrm{~kg} \mathrm{day}^{-1}\right)(\mathrm{P}<0.01)$. On the other

Table 2. Chemical composition of grass sampled at the time of ensiling and chemical composition and fermentation quality of grass silages preserved with different formic acid (FA) application rates $\left(0,2,4\right.$ and $\left.61 \mathrm{t}^{-1}\right)\left(\mathrm{g} \mathrm{kg}^{-1} \mathrm{dry} \mathrm{matter}\right.$ unless otherwise stated).

\begin{tabular}{|c|c|c|c|c|c|c|c|c|}
\hline & \multicolumn{4}{|c|}{ Grass } & \multicolumn{4}{|c|}{ Silages } \\
\hline & $\mathrm{FA}_{0}$ & $\mathrm{FA}_{2}$ & $\mathrm{FA}_{4}$ & $\mathrm{FA}_{6}$ & $\mathrm{FA}_{0}$ & $\mathrm{FA}_{2}$ & $\mathrm{FA}_{4}$ & $\mathrm{FA}_{6}$ \\
\hline Dry matter (DM), $\mathrm{g} \mathrm{kg}^{-1}$ & 254 & 269 & 277 & 269 & 250 & 260 & 267 & 266 \\
\hline Crude protein & 150 & 144 & 142 & 142 & 148 & 150 & 145 & 149 \\
\hline Ash & 97 & 92 & 93 & 93 & 98 & 95 & 98 & 97 \\
\hline Neutral-detergent fibre & & & & & 495 & 505 & 513 & 508 \\
\hline Acid-detergent fibre & & & & & 280 & 280 & 288 & 284 \\
\hline Lignin & & & & & 34 & 36 & 39 & 38 \\
\hline $\mathrm{pH}$ & & & & & 4.30 & 4.18 & 4.22 & 4.30 \\
\hline Water-soluble carbohydrates & 117 & 134 & 128 & 135 & 38 & 60 & 70 & 119 \\
\hline Lactic acid & & & & & 81 & 64 & 48 & 21 \\
\hline Acetic acid & & & & & 16 & 15 & 17 & 11 \\
\hline Propionic acid & & & & & 0.5 & 0.2 & 0.3 & 0.2 \\
\hline Butyric acid & & & & & 9.8 & 0.7 & 3.3 & 0.9 \\
\hline Total acids & & & & & 108 & 80 & 69 & 34 \\
\hline Ethanol & & & & & 8.4 & 10.4 & 9.6 & 7.7 \\
\hline Ammonia- $\mathrm{N}, \mathrm{g} \mathrm{kg}^{-1} \mathrm{~N}$ & & & & & 84 & 51 & 60 & 43 \\
\hline Soluble $\mathrm{N}, \mathrm{g} \mathrm{kg}^{-1} \mathrm{~N}$ & 353 & 257 & 260 & 259 & 616 & 530 & 526 & 498 \\
\hline Digestible organic matter in DM, $\mathrm{g} \mathrm{kg}^{-1}$ & & & & & 636 & 640 & 630 & 638 \\
\hline Metabolisable energy, $\mathrm{MJ} \mathrm{kg}^{-1} \mathrm{DM}^{1)}$ & & & & & 10.2 & 10.2 & 10.1 & 10.2 \\
\hline Amino acids absorbed in the small intestine ${ }^{1)}$ & & & & & 79.8 & 80.3 & 79.1 & 80.1 \\
\hline Protein balance in the rumen ${ }^{1)}$ & & & & & 12.3 & 12.8 & 10.3 & 12.0 \\
\hline Silage intake index ${ }^{2)}$ & & & & & 86.6 & 92.4 & 90.9 & 95.7 \\
\hline
\end{tabular}

1) According to MTT 2006

2) Calculated according to Huhtanen et al. (2002) 
Jaakkola, S. et al. Restriction of silage fermentation with formic acid

Table 3. Mean chemical composition of concentrates ( $\mathrm{g} \mathrm{kg}^{-1}$ dry matter, unless otherwise stated).

\begin{tabular}{lcccc}
\hline & Basic & $\begin{array}{c}\text { Basic }+ \\
\text { Rapeseed meal }\end{array}$ & $\begin{array}{c}\text { Basic }+ \\
\text { Propylene glycol }\end{array}$ & $\begin{array}{c}\text { Basic + Rapeseed meal } \\
\text { + Propylene glycol }\end{array}$ \\
\hline Dry matter (DM), g kg-1 & 890 & 889 & 887 & 886 \\
Ash & 67 & 74 & 67 & 76 \\
Crude protein & 131 & 179 & 129 & 178 \\
Neutral-detergent fibre & 287 & 289 & 285 & 286 \\
Ether extract & 31.2 & 37.2 & 29.7 & 35.5 \\
Amino acids absorbed in the & 98 & 109 & 98 & 109 \\
small intestine & -28 & 5 & -29 & 4 \\
Protein balance in the rumen & 11.5 & 11.6 & 11.5 & 11.5 \\
Metabolisable energy, MJ kg ${ }^{-1}$ DM & & & & \\
\hline
\end{tabular}

hand, PG inclusion tended to decrease silage DM intake $(\mathrm{P}<0.10)$.

Restriction of silage fermentation with FA curvilinearly increased milk $\left(\mathrm{P}_{\mathrm{L}}<0.01, \mathrm{P}_{\mathrm{C}}<0.05\right)$ and energy corrected milk $(\mathrm{ECM})$ yield $\left(\mathrm{P}_{\mathrm{Q}}<0.05\right)$ (Table 5). The highest milk yield was achieved with $\mathrm{FA}_{6}$, and the yield with $\mathrm{FA}_{2}$ was higher than with $\mathrm{FA}_{4}$. On the other hand, ECM yield was equal with $\mathrm{FA}_{2}$ and $\mathrm{FA}_{4}$ silages being $0.4 \mathrm{~kg}$ day $^{-1}$ lower than with $\mathrm{FA}_{0}$ and $1.2 \mathrm{~kg}$ day ${ }^{-1}$ lower than with $\mathrm{FA}_{6}$ silage. The use of RSM resulted in positive $(\mathrm{P}<$ $0.001)$ milk and ECM yield responses $(+1.6 \mathrm{~kg}$ day $^{-1}$ ) with all silages. For milk yield the response was $2.38,0.68,1.89$ and $1.30 \mathrm{~kg} \mathrm{~d}^{-1}$ for silages $\mathrm{FA}_{0}, \mathrm{FA}_{2}, \mathrm{FA}_{4}$ and $\mathrm{FA}_{6}$, respectively, and for $\mathrm{ECM}$ yield $2.11,1.01,2.63$ and $0.57 \mathrm{~kg}$, respectively (interaction $\mathrm{FA}_{\mathrm{C}} \mathrm{x}$ RSM, $\mathrm{P}<0.05$ ) (Fig. 1). The mean effect of $\mathrm{PG}$ on milk yield was $+0.4 \mathrm{~kg}$ day $^{-1}$ while the response was variable being $+0.36,-0.58$, +1.10 and $+0.46 \mathrm{~kg} \mathrm{~d}^{-1}$ for silages from $\mathrm{FA}_{0}$ to $\mathrm{FA}_{6}$, respectively (interaction $\mathrm{FA}_{\mathrm{C}} \times \mathrm{PG}, \mathrm{P}<0.05$ ). In ECM yield, no difference was observed in mean values while a significant interaction was observed between the three main factors suggesting a positive associative effect of RSM and PG only with silage $\mathrm{FA}_{4}$ and $\mathrm{FA}_{6}$ (interaction $\mathrm{FA}_{\mathrm{L}} \times \mathrm{RSM} \times \mathrm{PG}$, $\mathrm{P}<0.05$ ) (Fig. 1).

Increasing the rate of $\mathrm{FA}$ increased protein yield linearly $\left(\mathrm{P}_{\mathrm{L}}<0.01\right)$ while the response in protein concentration was curvilinear $\left(\mathrm{P}_{\mathrm{C}}<0.01\right)$. The use of RSM improved milk protein concentration
$(\mathrm{P}<0.05)$. Similarly, RSM had a positive effect on protein yield $(\mathrm{P}<0.001)$ with all silages, but the response was curvilinear being $+74,+27,+73$ and $+57 \mathrm{~g} \mathrm{~d}^{-1}$ for silages $\mathrm{FA}_{0}, \mathrm{FA}_{2}, \mathrm{FA}_{4}$ and $\mathrm{FA}_{6}$, respectively (interaction $\mathrm{FA}_{\mathrm{C}} \times \mathrm{RSM}, \mathrm{P}<0.05$ ). Similarly, the response to $\mathrm{PG}$ in protein yield was curvilinear $\left(+7,-13,+34\right.$ and $\left.-2 \mathrm{~g} \mathrm{~d}^{-1}\right)$ being highest with $\mathrm{FA}_{4}$ silage $\left(\mathrm{FA}_{\mathrm{C}} \times \mathrm{PG}, \mathrm{P}<0.05\right)$.

The effect of FA was not linear on milk fat concentration and yield $\left(\mathrm{P}_{\mathrm{Q}}<0.05\right)$. The fat concentration was highest with $\mathrm{FA}_{0}$ silage $\left(43.7 \mathrm{~g} \mathrm{~kg}^{-1}\right)$ and lowest with $\mathrm{FA}_{2}$ silage $\left(41.1 \mathrm{~g} \mathrm{~kg}^{-1}\right)$. The use of RSM improved milk fat secretion $(\mathrm{P}<0.01)$ (mean response $\left.+61 \mathrm{~g} \mathrm{~d}^{-1}\right)$ and the effect on milk fat concentration depended on silage quality being -1.1 , $+0.5,+2.1$ and $+2.5 \mathrm{~g} \mathrm{~kg}^{-1}$ for silages from $\mathrm{FA}_{0}$ to $\mathrm{FA}_{6}\left(\mathrm{FA}_{\mathrm{Q}} \times \mathrm{R}, \mathrm{P}<0.05\right)$. The decreasing effect of $\mathrm{PG}$ on milk fat concentration was consistent with all silages $(\mathrm{P}<0.05)$. Significant interactions were observed in fat concentration $\left(\mathrm{FA}_{\mathrm{C}} \times \mathrm{RSM} \times \mathrm{PG}, \mathrm{P}\right.$ $<0.01)$ and fat yield $\left(\mathrm{FA}_{\mathrm{L}},{ }_{\mathrm{C}} \times \mathrm{RSM} \times \mathrm{PG}, \mathrm{P}<0.05\right)$ which showed that the effect of PG on fat yield was positive without RSM and negative with RSM on diets $\mathrm{FA}_{0}$ and $\mathrm{FA}_{2}$. In contrast, on diets $\mathrm{FA}_{4}$ and $\mathrm{FA}_{6}$ the effect of PG was negative without RSM and positive with RSM (Fig. 1).

A small, but linear decrease was observed in milk lactose concentration with the increasing FA rate $\left(\mathrm{P}_{\mathrm{L}}<0.05\right)$, whereas the yield of lactose increased curvilinearly $\left(\mathrm{P}_{\mathrm{L}}, \mathrm{P}_{\mathrm{C}}<0.05\right)$. No significant effects of RSM and PG on lactose concentra- 
Vol. 15 (2006): 200-218.

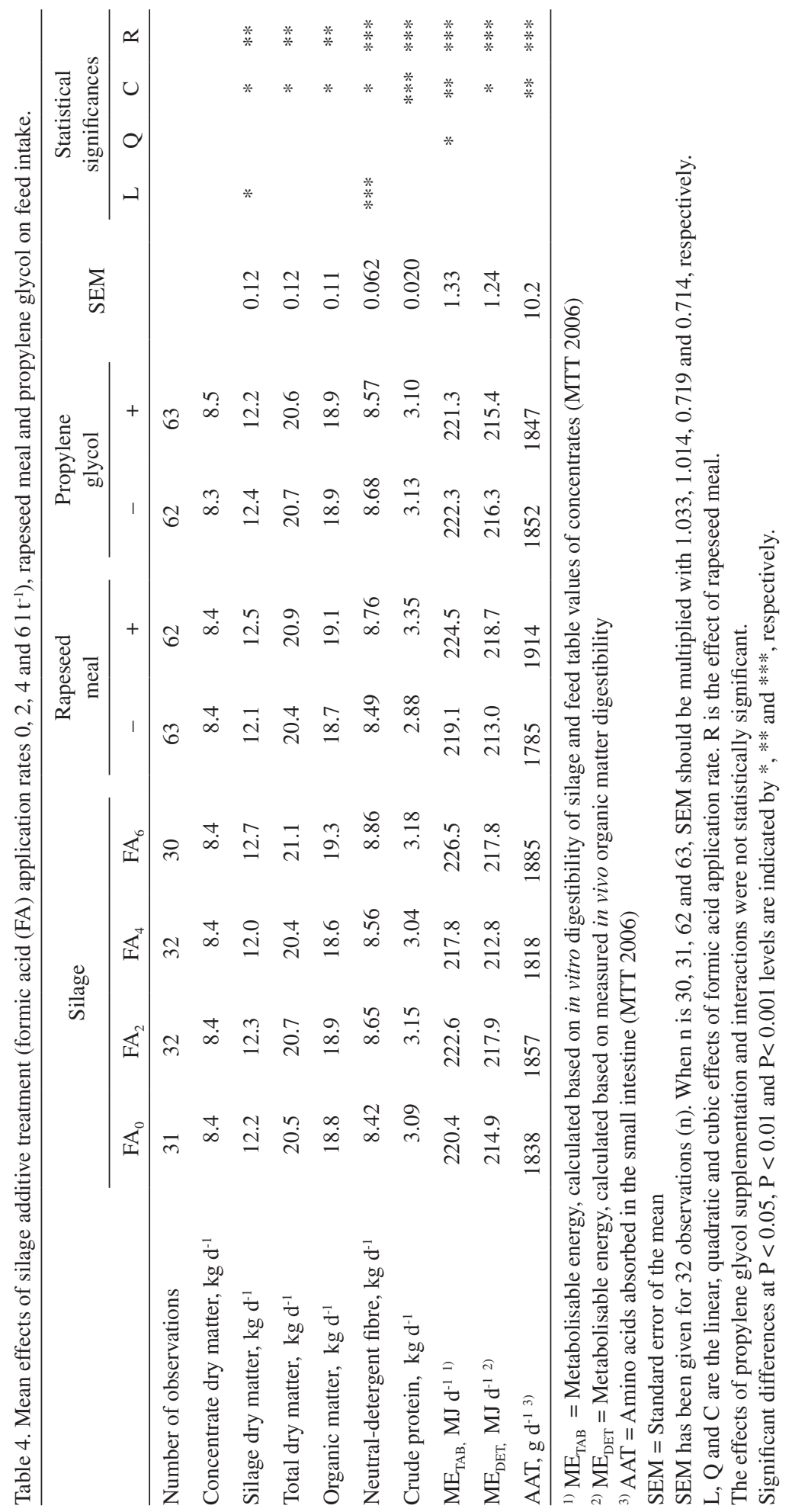


Jaakkola, S. et al. Restriction of silage fermentation with formic acid

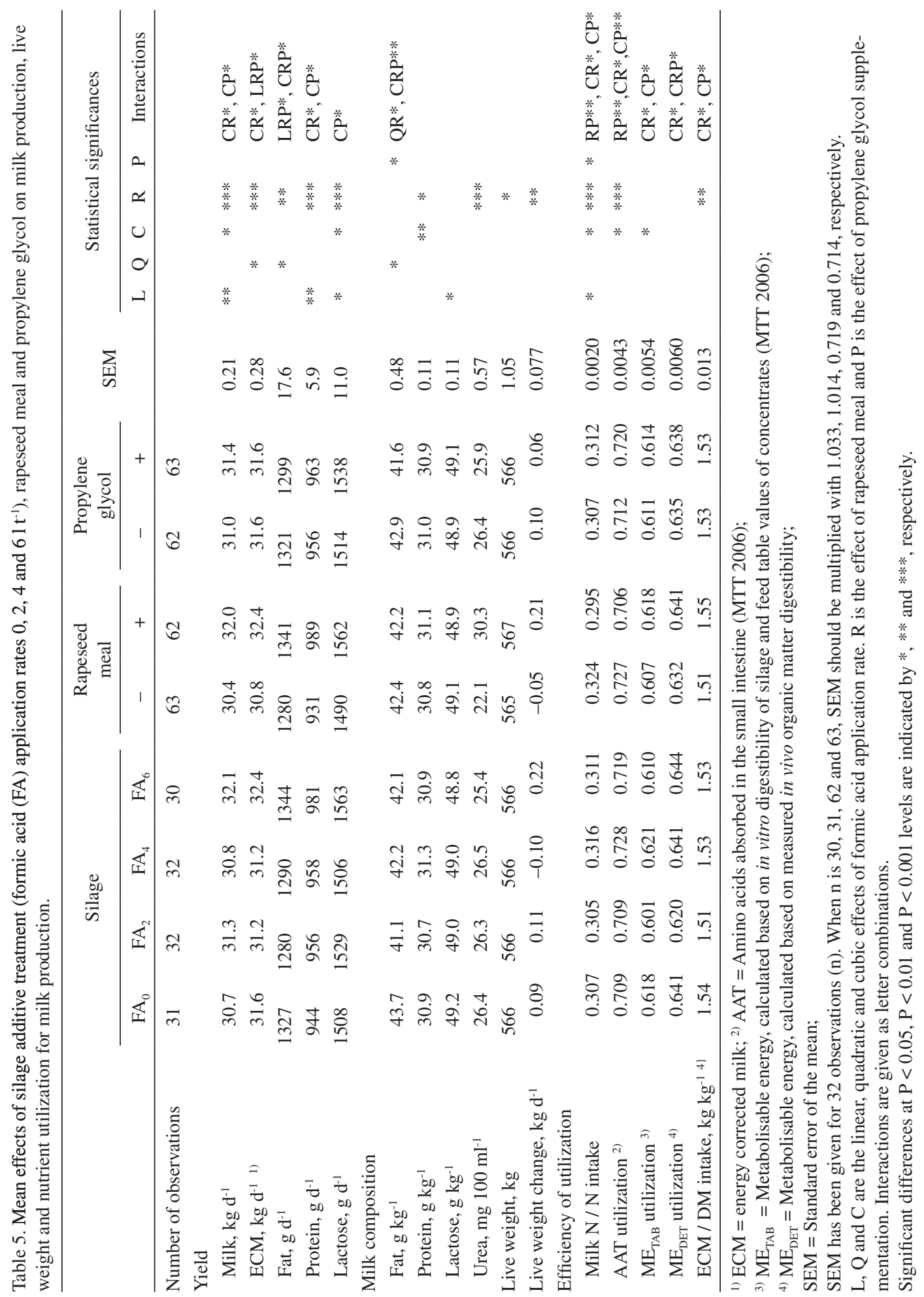


Vol. 15 (2006): 200-218.

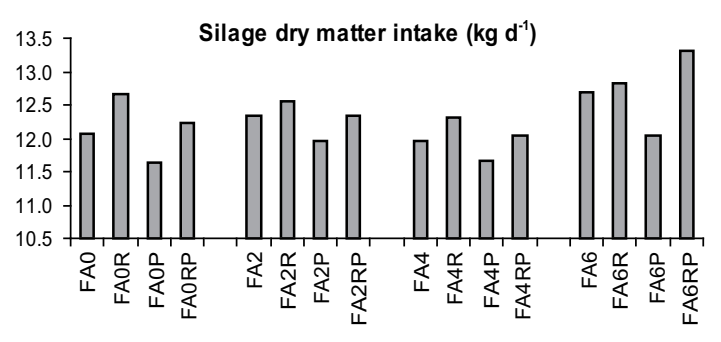

Fig. 1. Effects of silage additive treatment [formic acid (FA) application rates $0,2,4$ and $61 \mathrm{t}-1$ ], rapeseed meal (R) and propylene glycol (P) on milk production.
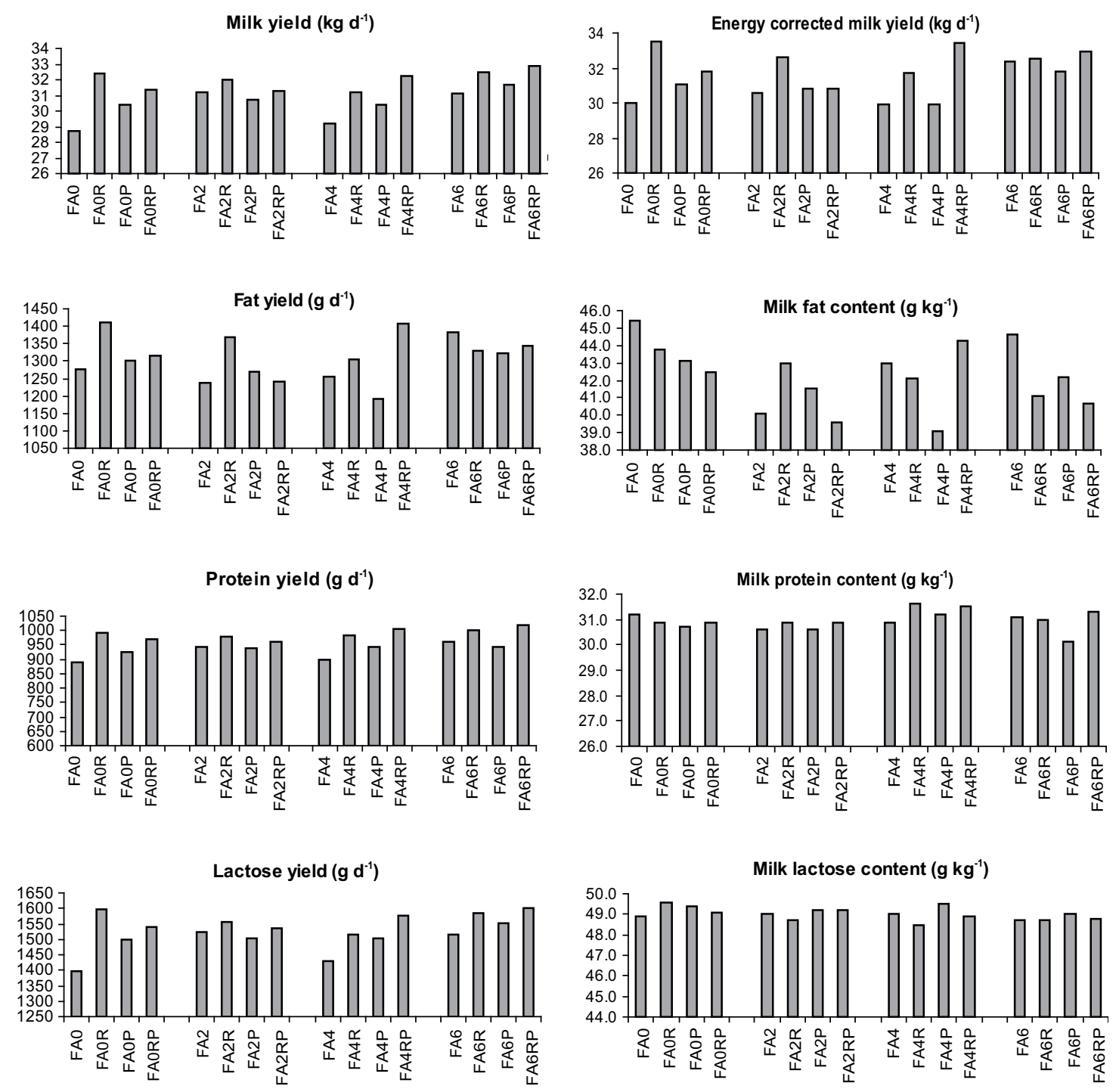
Jaakkola, S. et al. Restriction of silage fermentation with formic acid

tion were observed while RSM significantly increased lactose yield $(\mathrm{P}<0.001)$. The effect of $\mathrm{PG}$ on lactose yield was $+24,-21,+67$ and $+27 \mathrm{~g} \mathrm{~d}^{-1}$ with the silages $\mathrm{FA}_{0}$ to $\mathrm{FA}_{6}\left(\mathrm{FA}_{\mathrm{C}} \times \mathrm{PG}, \mathrm{P}<0.05\right)$. Milk urea concentration was not affected by FA application rate or PG supplementation, whereas RSM supplementation increased significantly $(\mathrm{P}<$ 0.001) milk urea concentration.

The efficiency of dietary $\mathrm{N}$ utilization, assessed as the ratio of milk N/N intake and AAT utilization, changed curvilinearly with the increasing rate of FA $\left(\mathrm{P}_{\mathrm{L}, \mathrm{C}}<0.05\right)$ (Table 5). The use of RSM depressed $\mathrm{N}$ utilization when assessed with the same criteria $(\mathrm{P}<0.001)$. In average, the use of PG supplement improved the efficiency of dietary N utilization. However, both the effects of RSM and PG depended on silage type.

Increasing the rate of FA linearly decreased $\mathrm{OM}(\mathrm{P}<0.05)$ and crude protein $(\mathrm{P}<0.01)$ digestibility, and influenced NDF digestibility curvilinearly $(\mathrm{P}<0.05)$ (Table 6). However, the differences were numerically small. Dietary PG inclusion had no effect $(\mathrm{P}>0.05)$ on digestibility, but RSM tended $(\mathrm{P}<0.10)$ to increase OM digestibility and significantly increased crude protein and NDF digestibility $(\mathrm{P}<0.001)$. However, a significant interaction was observed between quadratic effect of FA rate and $\mathrm{RSM}\left(\mathrm{FA}_{\mathrm{Q}} \times \mathrm{RSM}, \mathrm{P}<0.05\right)$. Without RSM the NDF digestibility was $0.586,0.597$, 0.600 and 0.575 for the diets $\mathrm{FA}_{0}, \mathrm{FA}_{2}, \mathrm{FA}_{4}$ and $\mathrm{FA}_{6}$, respectively. For diets including RSM, the respective values were $0.614,0.610,0.610$ and 0.603 .

Plasma glucose $(\mathrm{P}<0.01)$ and $\mathrm{B}-\mathrm{OHB}(\mathrm{P}<$ $0.001)$ concentrations changed in a cubic manner and urea concentration decreased linearly $\left(\mathrm{P}_{\mathrm{L}}<\right.$ 0.05 ) with the increasing FA rate (Table 6). Inclusion of RSM was associated with a clear increase in plasma urea concentration $(\mathrm{P}<0.001)$, but no other effects of RSM supplementation on plasma metabolites were observed. Plasma glucose concentration increased $(\mathrm{P}<0.001)$ and that of $\beta-\mathrm{OHB}$ decreased $(\mathrm{P}<0.001)$ with supplementation of PG. However, the effect of PG differed between the diets (interaction $\mathrm{FA}_{\mathrm{Q}} \times \mathrm{R} \times \mathrm{P}, \mathrm{P}<0.05$ ).

An increase in the FA application rate resulted in a linear $\left(\mathrm{P}_{\mathrm{L}}<0.05\right)$ decrease in the mean rumen
$\mathrm{pH}$ (Table 7) while the mean rumen ammonia $\mathrm{N}$ concentration changed in a quadratic manner $(\mathrm{P}<$ 0.05). The proportion of acetate in the rumen VFA increased $\left(\mathrm{P}_{\mathrm{L}},{ }_{\mathrm{Q}} \mathrm{P}<\right.$ at least 0.01$)$ and that of propionate decreased $\left(\mathrm{P}_{\mathrm{L}}<0.01\right)$ in response to the increasing rate of FA. Similarly, the proportions of isobutyric and isovaleric acid decreased $\left(\mathrm{FA}_{\mathrm{L}, \mathrm{Q}} \mathrm{P}<\right.$ at least 0.05). Consequently, the ratio of lipogenic to glucogenic VFA increased linearly $(\mathrm{P}<0.01)$ when silage fermentation was restricted. The changes in rumen fermentation pattern were not associated with changes $(\mathrm{P}>0.05)$ in rumen protozoal number with increasing FA level.

\section{Discussion}

\section{Fermentation quality of the silages}

Increasing the application rate of FA restricted silage fermentation as evidenced by decreased concentration of fermentation acids and an increased concentration of WSC. The extent and type of silage fermentation may be modified by differences in grass composition and epiphytic flora. Compared to our previous study with the same FA application rates (Jaakkola et al. 2006), the present grass had a higher DM (159 vs. $267 \mathrm{~g} \mathrm{~kg}^{-1}$ ) and WSC (72 vs. $129 \mathrm{~g} \mathrm{~kg}^{-1} \mathrm{DM}$ ) concentration, and therefore was easier to ensile. As a result, the untreated silage underwent a predominantly lactic fermentation. The higher concentration of butyric and propionic acid and the higher concentration of ammonia $\mathrm{N}$ and soluble $\mathrm{N}$ indicate slightly lower quality as compared with FA-treated silages. On the other hand, $\mathrm{FA}_{4}$ silage had higher butyric acid concentration than other FA silages. In addition, proteolysis was restricted in a curvilinear manner by the FA treatment as $\mathrm{FA}_{4}$ had a higher proportion of ammonia $\mathrm{N}$ than $\mathrm{FA}_{2}$.

The results resemble those of Chamberlain and Quig (1987), who observed that FA at $41 \mathrm{t}^{-1}$ produced badly fermented silage while 2 and $61 \mathrm{t}^{-1}$ produced well fermented silage. In the experiment of Jaakkola et al. (2006), the effect of FA applica- 
Vol. 15 (2006): 200-218.

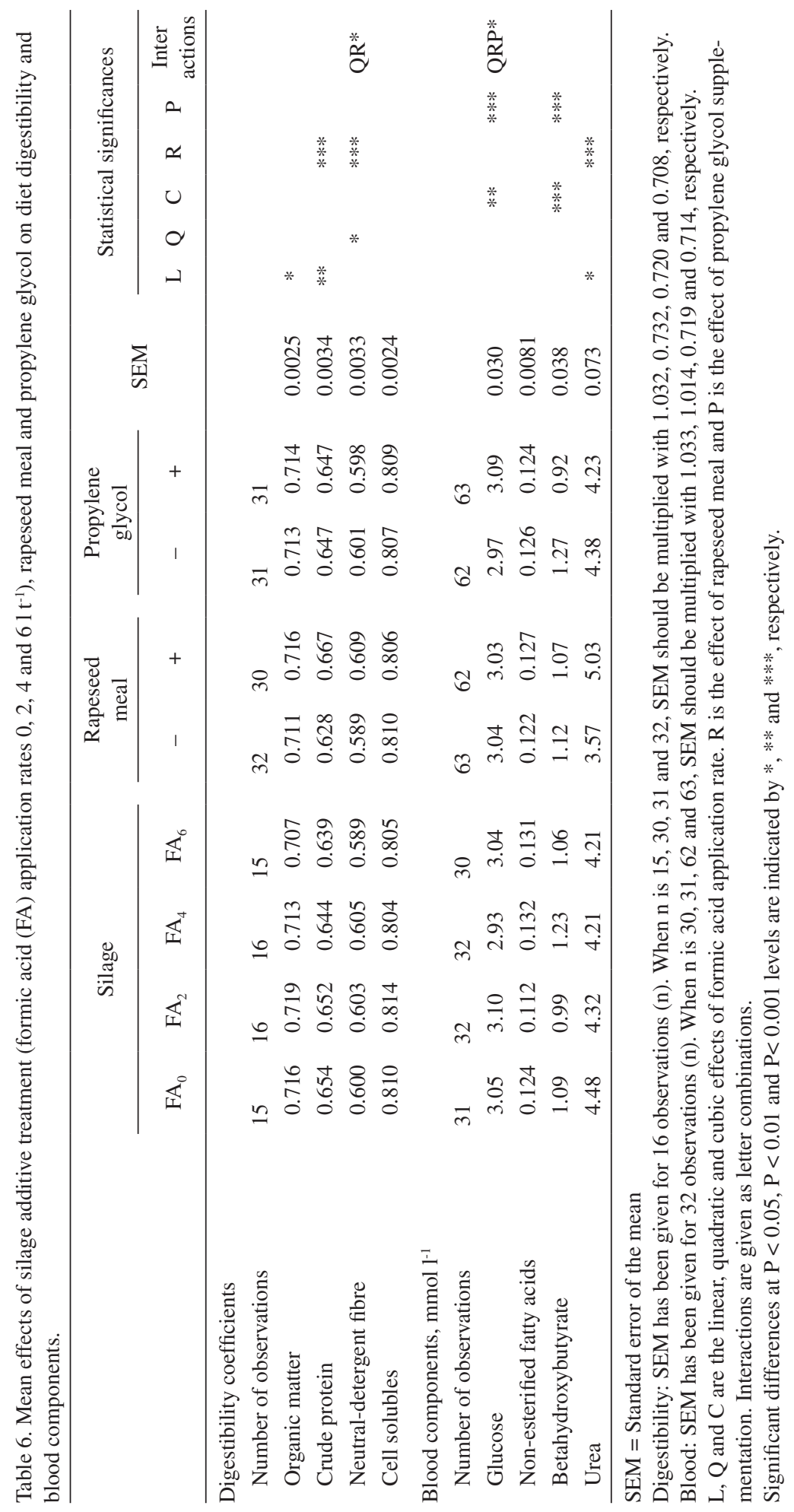


Jaakkola, S. et al. Restriction of silage fermentation with formic acid

Table 7. Mean effects of silage additive treatment (formic acid (FA) application rates $0,2,4$ and $61 \mathrm{t}^{-1}$ ) on rumen fermentation of ruminally fistulated cows.

\begin{tabular}{|c|c|c|c|c|c|c|c|}
\hline & \multicolumn{4}{|c|}{ Silage } & \multirow{2}{*}{ SEM } & \multicolumn{2}{|c|}{$\begin{array}{c}\text { Statistical } \\
\text { significances }\end{array}$} \\
\hline & $\mathrm{FA}_{0}$ & $\mathrm{FA}_{2}$ & $\mathrm{FA}_{4}$ & $\mathrm{FA}_{6}$ & & $\mathrm{~L}$ & Q \\
\hline $\mathrm{pH}$ & 6.49 & 6.44 & 6.35 & 6.38 & 0.037 & $*$ & \\
\hline Ammonia $\mathrm{N}, \mathrm{mmol} \mathrm{l}^{-1}$ & 14.0 & 11.4 & 11.2 & 12.4 & 0.58 & & * \\
\hline Total volatile fatty acids (VFA), mmol $\mathrm{l}^{-1}$ & 110.2 & 116.1 & 115.7 & 114.1 & 1.74 & & \\
\hline \multicolumn{8}{|l|}{ Molar proportions of VFA, $\mathrm{mmol} \mathrm{mol}^{-1}$} \\
\hline Acetic acid (AA) & 636 & 657 & 672 & 669 & 2.5 & $* * *$ & $* *$ \\
\hline Propionic acid (PA) & 179 & 168 & 156 & 158 & 4.0 & $* *$ & \\
\hline Butyric acid (BA) & 137 & 132 & 130 & 131 & 2.5 & & \\
\hline Isobutyric acid & 10.5 & 9.0 & 8.3 & 8.6 & 0.24 & $* * *$ & $*$ \\
\hline Valeric acid & 14.3 & 14.3 & 13.4 & 14.0 & 0.33 & & \\
\hline Isovaleric acid & 15.3 & 13.0 & 11.4 & 11.8 & 0.35 & $* * *$ & $*$ \\
\hline Caproic acid & 8.1 & 7.8 & 8.8 & 7.4 & 0.43 & & \\
\hline$(\mathrm{AA}+\mathrm{BA}) / \mathrm{PA}$ & 4.43 & 4.75 & 5.17 & 5.12 & 0.126 & $* *$ & \\
\hline Protozoa, $\times 10^{5} \mathrm{ml}^{-1}$ & 1.91 & 2.10 & 1.69 & 1.63 & 0.165 & & \\
\hline
\end{tabular}

$\mathrm{SEM}=$ Standard error of the mean

$\mathrm{L}$ and $\mathrm{Q}$ are the linear and quadratic effects of formic acid application rate. Cubic effects were not significant.

Significant differences at $\mathrm{P}<0.05, \mathrm{P}<0.01$ and $\mathrm{P}<0.001$ levels are indicated by $* * *$ and $* * *$, respectively.

tion rate on fermentation and $\mathrm{pH}$ was more linear with increasing rate of FA. The curvilinear change in $\mathrm{pH}$ in the present study support the conclusion of Leibensperger and Pitt (1988) that silage $\mathrm{pH}$ can be either increased or decreased by FA addition depending on application rate, crop DM concentration, and other parameters. The effects of FA in silage are due both to direct acidification and antimicrobial properties. This implies that the effect of FA on the balance and survival of desirable and undesirable microorganisms may modify the fermentation in very diverse ways.

The ratio of fermentation acids to residual WSC was 2.8 in untreated silage, and 1.3, 1.0 and 0.3 in $\mathrm{FA}_{2}, \mathrm{FA}_{4}$ and $\mathrm{FA}_{6}$ silages, respectively. This indicates a different nutrient supply to rumen microbes when the silages are fed to cattle. The differences between silages were much smaller than in the physiological study (Jaakkola et al. 2006) in which the above mentioned ratio was 42.0, 5.1, 1.6 and 0.3 for silage $\mathrm{FA}_{0}$ to $\mathrm{FA}_{6}$. The difference between experiments is mediated through higher WSC concentration in the present silages and higher DM concentration which means no WSC losses in effluent. In the present experiment, $\mathrm{FA}_{2}$ silage was exceptionally close to $\mathrm{FA}_{4}$ silage in terms of fermentation profile.

\section{Intake}

Intake results were not related to digestibility data, since FA application rate had no marked effect on OM digestibility in accordance with earlier experiments using sheep (Chamberlain et al. 1982) and cattle (Jaakkola et al. 2006). In general, the effect of FA treatment on silage intake depends on the application rate and the material ensiled (Harrison et al. 2003), and consequently on the fermentation quality of the silage. In the present experiment, the fermentation pattern achieved by the FA treatment modified the intake rather than the application rate per se. This shows that the effect of FA rate on silage fermentation is not always predictable. Lower intake with $\mathrm{FA}_{0}$ and $\mathrm{FA}_{4}$ silages compared with other silages can be attributed to the greater extent 
Vol. 15 (2006): 200-218.

of proteolysis and secondary fermentation as evidenced by higher ammonia N and VFA concentrations which are known to influence silage intake negatively (Huhtanen et al. 2002). However, compared to $\mathrm{FA}_{2}$ and $\mathrm{FA}_{4}$ silages, the intake of $\mathrm{FA}_{0}$ silage was higher than expected from the general relationship between fermentation quality and intake (Huhtanen et al. 2002).

Highest application rate of FA improved silage DM intake by 0.42 to $0.72 \mathrm{~kg} \mathrm{~d}^{-1}(3.5-6.0 \%)$ as compared with the other treatments. The responses are in line with observations in experiments where restrictively fermented FA silage has been compared with more extensively fermented inoculated silages (Heikkilä et al. 1998, Shingfield et al. 2002a). In a literature review by Harrison et al. (1994), FA treatment increased intake of direct-cut silage by 2.3 to $15.2 \%$ and that of wilted material by $0.4 \%$ to $9.6 \%$ as compared with untreated silage.

Due to the RSM supplementation, a mean increase of $0.025 \mathrm{~kg}$ silage DM per $\mathrm{g} \mathrm{kg}^{-1}$ additional crude protein in the diet was observed. This was in agreement with previous observations on grass silage diets supplemented with RSM (Tuori 1992, Huhtanen 1998). Although no significant interaction was observed, the response varied with the experimental silages being highest with $\mathrm{FA}_{0}$ and $\mathrm{FA}_{6}$ silages (0.6 and $\left.0.7 \mathrm{~kg} \mathrm{DM} \mathrm{d}^{-1}\right)$ and lowest with $\mathrm{FA}_{2}$ and $\mathrm{FA}_{4}$ silages $\left(0.3\right.$ and $\left.0.4 \mathrm{~kg} \mathrm{DM} \mathrm{d}^{-1}\right)$. The intake responses to protein supplementation in grass silage based diets are thought to be mediated through improved nutrient balance (amino acids: $\mathrm{ME}$ ). Thus the result of the present experiment suggests that the ratio might have been more unbalanced with $\mathrm{FA}_{0}$ and $\mathrm{FA}_{6}$ silages than other experimental silages. For $\mathrm{FA}_{0}$ silage the unbalance might be explained by low amino acid supply while for FA6 silage the high silage and ME intake may have caused the imbalance. Although RSM inclusion increased NDF digestibility, the effect on OM digestibility was probably too small to explain the increased DM intake.

Supplementation with PG tended to decrease silage DM intake (mean $-0.28 \mathrm{~kg} \mathrm{DM}$ ) irrespective of silage fermentation characteristics. Other studies have shown either increased intake (Cozzi et al.
1996), decreased intake (Dhiman et al. 1993) or no effects on forage intake (Shingfield et al. 2002a). In the present experiment, the intake depression of forage might be explained by the higher ME intake from the $\mathrm{PG}$ concentrate leading to equal total $\mathrm{ME}$ intake in the $-\mathrm{PG}$ and $+\mathrm{PG}$ diets.

\section{Milk production}

Restriction of silage fermentation with increasing FA level increased milk and milk component yields in a curvilinear manner. The result is consistent with the observations that the effects of silage fermentation on milk production largely depends on changes in intake (Harrison et al. 2003). In an analysis of literature data, yields of milk, ECM, protein and fat decreased with the increasing extent of in-silo fermentation, the concentration of total fermentation acids (lactic acid + VFA) being the best single predictor of production parameters (Huhtanen et al. 2003).

Reflecting the pattern of silage intake, the highest milk yield was achieved with $\mathrm{FA}_{6}$, while the yield with $\mathrm{FA}_{2}$ was higher than with $\mathrm{FA}_{4}$. Similarly the highest protein yield was obtained with $\mathrm{FA}_{6}$ silage, but no difference was observed between $\mathrm{FA}_{2}$ and $\mathrm{FA}_{4}$ silages. The increasing protein yield with the FA rate is consistent with our previous physiological study (Jaakkola et al. 2006) in which restriction of silage fermentation by FA was positively related to the synthesis of microbial protein in the rumen and microbial $\mathrm{N}$ flow at the duodenum. The rather small effect of the lower FA rates ( 2 and 4 litres) can probably be explained by the relatively good quality of untreated $\mathrm{FA}_{0}$ silage. $\mathrm{Ab}$ sence of clear improvements in animal performance in response to FA treatment has been reported when untreated control silages were well preserved (Mayne 1993, Smith et al. 1993).

The responses to FA treatment may be attributed to the appearance of both positive and negative effects of silage fermentation on the nutrient supply. In addition to silage intake and microbial protein flow, the effects of silage composition on rumen fermentation may account for part of the changes especially in the relative changes in milk 
Jaakkola, S. et al. Restriction of silage fermentation with formic acid

component yields. Despite differences in milk protein yield, only minor changes were observed in the milk protein concentration between silages. This is in contrast with other reports where the general trend has been that restricted silage fermentation increases milk protein concentration (Huhtanen 1993, Cushnahan and Mayne 1995, Shingfield et al. 2002a).

As compared to protein concentration, more variation was observed in milk fat concentration between silages. The lower fat concentration with $\mathrm{FA}_{2}$ silage than $\mathrm{FA}_{4}$ and $\mathrm{FA}_{6}$ silages is consistent with several studies in which cows offered restrictively fermented silage have produced milk with a greater concentration and yield of fat than those offered extensively fermented silage (Chamberlain et al. 1992, Cushnahan and Mayne 1995). The result can be explained by a strong correlation between silage fermentation and rumen fermentation profiles. Lactic acid intake leads to increased molar proportion of propionic acid in the rumen VFA (Jaakkola and Huhtanen 1992, Martin et al. 1994), while more restrictively fermented silage has increased acetate and/or butyrate proportion in the rumen VFA (Huhtanen et al. 1997, Smith et al. 1993). Consistently, in the present experiment and in the experiment of Jaakkola et al. (2006), restricting silage fermentation with a high application rate of FA ( 4 and 6 litres) induced a rumen VFA pattern with a relatively high proportion of lipogenic VFAs as compared with feeding silages treated with a lower rate of FA. In the experiments of Cushnahan and Mayne (1995) and Cushnahan et al. (1995), a similar fat concentration was achieved with fresh grass and restrictively fermented silage.

An unexpected result occurred with the feeding of untreated silage. It induced the highest milk fat concentration despite being the most extensively fermented silage. Similar results were obtained in the study of Saarisalo et al. (2002), in which the use of extensively fermented untreated silage resulted in higher milk fat concentration and yield as compared to feeding of FA-treated silage. The relatively high concentration of WSC and butyric acid in the $\mathrm{FA}_{0}$ silage might partly explain the confusing result. However, the rumen fermentation results do not support this, since the (acetate + bu- tyrate)/propionate-ratio was the lowest with $\mathrm{FA}_{0}$ silage. In addition, the contribution of silage butyric acid is expected to be of minor importance as compared with that produced in the rumen. Thus it seems that the causative effects of silage quality on milk fat concentration and yield are not entirely clear.

Supplementary concentrates were used to improve the nutritional shortcomings of the silages. Some of the observed interactions between the extent of silage fermentation and the composition of the concentrate support the conclusion that the nutrient supply depends on silage fermentation which further determines the extent of response to concentrates.

The mean response to protein supplementation was $0.89 \mathrm{~kg}$ milk (and ECM) and $32.2 \mathrm{~g}$ milk protein per $\mathrm{kg}$ of RSM. The values are slightly lower than the mean values $(1.05 \mathrm{~kg}, 39.4 \mathrm{~g})$ in a literature review of studies in Finland (Huhtanen 1998). Large variation was observed between the different silages so that the highest responses in milk and protein yield were observed with $\mathrm{FA}_{0}$ silage (1.32 kg and $40.9 \mathrm{~g}$ per $\mathrm{kg}$ RSM) and lowest with $\mathrm{FA}_{2}$ silage $(0.38 \mathrm{~kg}$ and $15.5 \mathrm{~g})$. The result with $\mathrm{FA}_{0}$ silage support the hypothesis that milk yield response to protein supplement could be higher on diets based on extensively fermented silages which are more limited in the supply of amino acids.

Diets based on restrictively fermented silage are suggested to be more limited in nutrients providing precursors for gluconeogenesis in animal than extensively fermented silages. Silages having relatively high WSC concentration and low lactic acid concentration maintain rumen fermentation pattern rich in acetate and butyrate and low in propionate (Huhtanen 1998). This finding is supported by the lower plasma glucose concentrations in cows fed restrictively fermented silage (Miettinen and Huhtanen 1997, Heikkilä et al. 1998) caused by lower proportion of propionate in the rumen VFA. This would imply that the cows fed with restrictively fermented silage may benefit most from the glucogenic nutrient source. In the present experiment, the average milk yield response to PG supplementation was $0.4 \mathrm{~kg} \mathrm{~d}^{-1}$ the highest response being observed with $\mathrm{FA}_{4}(+1.10 \mathrm{~kg})$ and 
Vol. 15 (2006): 200-218.

$\mathrm{FA}_{6}(+0.46 \mathrm{~kg})$ silages. Consistently, the lowest plasma glucose concentration without PG was observed with the $\mathrm{FA}_{4}$ silage. However, no difference was observed between diets $\mathrm{FA}_{0}$ and $\mathrm{FA}_{6}$ in plasma glucose without PG despite a difference in the amount of silage lactic acid and consequently a difference in mean rumen propionate proportion in the companion study. Supplementing the diet with PG increased plasma glucose concentration being in agreement with other studies (Grummer et al. 1994, Shingfield et al. 2002b). The response was greatest with untreated silage while for FA-treated silages the response increased with the level of FA application rate. With FA silages, the result supports the conclusion that diets based on restrictively fermented silages are more limited in glucose precursors and the cows benefit more from PG than those having extensively fermented silages. The result with untreated silage suggests that the positive effect of high lactic acid concentration on rumen propionate is partly lost due to other limitations in silage composition.

The decreasing effect of PG on milk fat concentration was consistent with all silages. As a consequence the mean effect of PG on ECM yield and fat yield was negative with the exception of $\mathrm{FA}_{4}$. Although PG had no significant effects on milk protein concentration, interaction with silage type was observed in protein yield. PG increased protein yield with $\mathrm{FA}_{4}$ silage $\left(+34 \mathrm{~g} \mathrm{~d}^{-1}\right)$ while it had a small or even negative effect with other silages $\left(-13-+7 \mathrm{~g} \mathrm{~d}^{-1}\right)$. In the study of Shingfield et al. (2002a), dietary inclusion of PG had no effects on ECM and milk protein yield, while in agreement with the present study, PG decreased milk fat concentration. Shingfield et al. (2002a) concluded that the use of PG was unable to compensate for variations in animal performance due to forage conservation method. In the present experiment, the positive effects of PG on ECM and protein yields were observed on diets based on $\mathrm{FA}_{4}$ and $\mathrm{FA}_{6}$ silage when the diet was also supplemented with RSM. At least with $\mathrm{FA}_{6}$ this may indicate that increased glucose supply from PG allowed increased AA supply both from microbial protein and RSM to be efficiently used for milk protein synthesis.

\section{Conclusions}

The results of the present experiment were obviously affected by the relatively high WSC and DM concentration of unwilted grass which affects the response to FA compared to a situation using grass possessing more challenging ensiling characteristics. It seems that the effect of increasing application rate of formic acid on silage fermentation and chemical composition varies and is not necessarily linear, which probably is associated to the effects of FA on epiphytic flora. Restriction of silage fermentation with a high rate of formic acid $\left(6 \mathrm{lt}^{-1}\right)$ seemed to be beneficial to milk production in the present experiment. The use of restrictively fermented silage led to high silage intake and high milk and protein yields. Silage of moderate lactic acid fermentation may also lead to a good result provided that this can be achieved without secondary fermentation in the silage. Production response to rapeseed meal was highest with untreated silage while propylene glycol was most beneficial with restrictively fermented silage. Interactions between silage composition and concentrate types support the use of different supplementation for different types of silages.

Acknowledgements. The authors wish to acknowledge the technical assistance and cooperation of the staff in Lintupaju Experimental Farm, and other staff of Animal Nutrition and Jokioinen Estates, MTT Agrifood Research Finland. We thank Lännen Tehtaat for the cooperation.

\section{References}

Chamberlain, D.G., Martin, P.A., Robertson, S. \& Hunter, E.A. 1992. Effects of the type of additive and the type of supplement on the utilization of grass silage for milk production in dairy cows. Grass and Forage Science 47: 391-399.

Chamberlain, D.G. \& Quig, J. 1987. The effect of the rate of addition of formic acid and sulphuric acid on the ensilage of perennial ryegrass in laboratory silos. Journal of the Science of Food and Agriculture 38: 217-228.

Chamberlain, D.G., Thomas, P.C. \& Wait, M.K. 1982. The rate of addition of formic acid to grass at ensilage and 
Jaakkola, S. et al. Restriction of silage fermentation with formic acid

the subsequent digestion of the silage in the rumen and intestines of sheep. Grass and Forage Science 37: 159-164.

Cushnahan, A. \& Mayne, C.S. 1995. Effects of ensilage of grass on performance and nutrient utilization by dairy cattle. 1. Food intake and milk production. Animal Science 60: 337-345.

Cushnahan, A., Mayne, C.S. \& Unsworth, E.F. 1995. Effects of ensilage of grass on performance and nutrient utilization by dairy cattle. 2 . Nutrient metabolism and rumen fermentation. Animal Science 60: 347-359.

Cozzi, G., Berzaghi, P., Gottardo, F., Gabai, G. \& Andrighetto, I. 1996. Effects of feeding propylene glycol to midlactating dairy cows. Animal Feed Science and Technology 64: 43-51.

Davis, A.W. \& Hall, W.B. 1969. Cyclic change-over designs. Biometrika 56: 283-293.

Dhiman, T.R., Cadorniga, C. \& Satter, L.D. 1993. Protein and energy supplementation of alfalfa silage diets during early lactation. Journal of Dairy Science 76: 19451959.

Gordon, F.J. 1989. An evaluation through lactating cattle of a bacterial inoculant as an additive for grass silage. Grass and Forage Science 44: 169-179.

Grummer, R.R., Winkler, J.C., Bertics, S.J. \& Studer, V.A. 1994. Effect of propylene glycol dosage during feed restriction on metabolites in blood of prepartum Holstein heifers. Journal of Dairy Science 77: 3618-3623.

Harrison, J.H., Blauwiekel, R. \& Stokes, M.R. 1994. Fermentation and utilization of grass silage. Journal of Dairy Science 77: 3209-3235.

Harrison, J., Huhtanen, P. \& Collins, M. 2003. Perennial grasses. In: Buxton, D.R. et al. (eds.). Silage science and technology book. Agronomy Monograph no. 42. p. 665-747.

Heikkilä, T., Toivonen, V. \& Huhtanen, P. 1998. Effects of and interactions between the extent of silage fermentation and protein supplementation in lactating dairy cows. Agricultural and Food Science in Finland 7: 329-343.

Huhtanen, P. 1993. Forage influences on milk composition. In: Fredeen, A.H. (ed.). Proceedings of the Nova Scotia Forage Conference: Forage: Seeding to feeding, Dartmouth, N.S., 29-30 October 1993. Truro: The Nova Scotia Forage Council. p. 144-162.

Huhtanen, P. 1998. Supply of nutrients and productive responses in dairy cows given diets based on restrictively fermented silage. Agricultural and Food Science in Finland 7: 219-250.

Huhtanen, P. \& Heikkilä, T. 1996. Effects of physical treatment of barley and rapeseed meal in dairy cows given grass silage-based diets. Agricultural and Food Science in Finland 5: 399-412.

Huhtanen, P., Khalili, H., Nousiainen, J.I., Rinne, M., Jaakkola, S., Heikkilä, T. \& Nousiainen, J. 2002. Prediction of the relative intake potential of grass silage by dairy cows. Livestock Production Science 73: 111-130.

Huhtanen, P., Miettinen, H. \& Toivonen, V. 1997. Effects of silage fermentation and post-ruminal casein supplementation in lactating dairy cows. 1. Diet digestion and milk production. Journal of the Science of Food and Agriculture 74: 450-458.

Huhtanen, P., Nousiainen, J.I., Khalili, H., Jaakkola, S. \&
Heikkilä, T. 2003. Relationships between silage fermentation characteristics and milk production parameters: analyses of literature data. Livestock Production Science 81: 57-73.

Huida, L. 1982. Gas chromatographic determination of water and ethanol in silage by internal standard method. Journal of the Scientific Society of Agricultural Science in Finland 54: 137-143.

Jaakkola, S. \& Huhtanen, P. 1992. Rumen fermentation and microbial protein synthesis in cattle given intraruminal infusions of lactic acid with grass silage based diet. Journal of Agricultural Science, Cambridge 119: 411418.

Jaakkola, S., Kaunisto, V. \& Huhtanen, P. 2006. Volatile fatty acids proportions and microbial protein synthesis in the rumen of cattle receiving grass silage ensiled with different rates of formic acid. Grass and Forage Science 61: 282-292.

Jaakkola, S., Rinne, M., Heikkilä, T., Toivonen, V. \& Huhtanen, P. 1996. Effects of restriction of silage fermentation with formic acid on milk production. In: Jones, D. I.H. et al. (eds.). Proceedings of the 11th International Silage Conference, IGER, Aberystwyth, UK. p. 76-77.

Kung, L., Jr., Stokes, M.R. \& Lin, C.J. 2003. Silage additives. In: Buxton, D.R. et al. (eds.). Silage science and technology book. Agronomy Monograph no. 42. p. 305360.

Leibensperger, R.Y. \& Pitt, R.E. 1988. Modelling the effects of formic acid and molasses on ensilage. Journal of Dairy Science 71: 1220-1231.

McDonald, P., Edwards, R.A., Greenhalgh, J.F.D. \& Morgan, C.A. 1995. Animal nutrition. Fifth Edition. Singapore, Longman Singapore Publishers Ltd. 607 p.

MAFF 1975. Energy allowances and feeding systems for ruminants. Ministry of Agriculture, Fisheries and Food. Technical Bulletin 33. Her majesty's Stationery Office, London. $79 \mathrm{p}$.

MAFF 1984. Energy allowances and feeding systems for ruminants. Ministry of Agriculture, Fisheries and Food. Reference Book 433. Her Majesty's Stationary Office, London. 85 p.

Martin, P.A., Chamberlain, D.G., Robertson, S. \& Hirst, D. 1994. Rumen fermentation patterns in sheep receiving silages of different chemical composition supplemented with concentrates rich in starch or in digestible fibre. Journal of Agricultural Science, Cambridge 122: 145150.

Mayne, C.S. 1990. An evaluation of an inoculant of Lactobacillus plantarum as an additive for grass silage for dairy cattle. Animal Production 51: 1-13.

Mayne, C.S. 1993. The effect of formic acid, sulphuric acid and a bacterial inoculant on silage fermentation and the food intake and milk production of lactating dairy cows. Animal Production 56: 29-42.

Miettinen, H. \& Huhtanen, P. 1997. Effects of silage fermentation and postruminal casein supplementation in lactating dairy cows. 2. Blood metabolites and amino acids. Journal of the Science of Food and Agriculture 74: 459-468.

MTT 2006. Rehutaulukot ja ruokintasuositukset (Feed tables and feeding recommendations). Jokioinen: MTT Agrifood Research Finland. Updated 14 Feb 2006, cit- 


\section{AGRICULTURAL AND FOOD SCIENCE}

Vol. 15 (2006): 200-218.

ed 12 June 2006. Available on the Internet: http://www. agronet.fi/rehutaulukot/. URN:NBN:fi-fe20041449.

Nousiainen, J., Rinne, M., Hellämäki, M. \& Huhtanen, P. 2003. Prediction of the digestibility of the primary growth of grass silages harvested at different stages of maturity from chemical composition and pepsin-cellulase solubility. Animal Feed Science and Technology 103: 97-111.

Rinne, M., Jaakkola, S., Varvikko, T. \& Huhtanen, P. 1999. Effects of the type and amount of rapeseed feed on milk production. Acta Agriculturae Scandinavica, Section A, Animal Science 49: 137-148.

Saarisalo, E., Jaakkola, S. \& Skyttä, E. 2002. Effect of lactic acid bacteria inoculant on fermentation quality of wilted silage and on milk production. In: Gechie, L.M. \& Thomas, C. (eds.). Conference Proceedings of the 13th International Silage Conference, Auchincruive, SAC, UK. p. 214-215.

SAS $®$ 1989. SAS/STAT $\circledast$ User's guide. Version 6, fourth edition. Statistical Analysis Systems Institute Inc., Cary, North Carolina.

Shingfield, K.J., Jaakkola, S. \& Huhtanen, P. 2001. Effects of level of nitrogen fertilizer application and various nitrogenous supplements on milk production and nitrogen utilization of dairy cows given grass silage-based diets. Animal Science 73: 541-554.

Shingfield, K.J., Jaakkola, S. \& Huhtanen, P. 2002a. Effect of forage conservation method, concentrate level and propylene glycol on intake, feeding behaviour and milk production of dairy cows. Animal Science 74: 383397.
Shingfield, K.J., Jaakkola, S. \& Huhtanen, P. 2002b. Effect of forage conservation method, concentrate level and propylene glycol on diet digestibility, rumen fermentation, blood metabolite concentrations and nutrient utilisation of dairy cows. Animal Feed Science and Technology 97: 1-21.

Sjaunja, L.O., Baevre, L., Junkkarinen, L., Pedersen, J. \& Setälä, J. 1990. A Nordic proposal for an energy corrected milk (ECM) formula. Proceedings of the 27 th biennal session of the International Committee for Animal Recording (ICAR), Paris, France. EAAP publication No. 50. p. 156.

Smith, E.J., Henderson, A.R., Oldham, J.D., Whitaker, D.A., Aitchinson, K., Anderson, D.H. \& Kelly, J.M. 1993. The influence of an inoculant/enzyme preparation as an additive for grass silage offered in combination with three levels of concentrate supplementation on performance of lactating dairy cows. Animal Production 56: 301310.

Snedecor, G.W. \& Cochran, W.G. 1967. Statistical methods. 6th edition Ames, lowa, USA. The lowa State University Press.

Tuori, M. 1992. Rapeseed meal as a supplementary protein for dairy cows on grass silage-based diet, with the emphasis on the Nordic AAT-PBV feed protein evaluation system. Agricultural Science in Finland 1: 367-439.

Van Keulen, J. \& Young, B.A. 1977. Acid insoluble ash as a natural marker for digestibility studies. Journal of Animal Science 44: 282-287. 


\title{
SELOSTUS
}

\section{Muurahaishapon annostelutason, rypsirouheen ja propyleeniglykolin vaikutukset maidontuotantoon}

\author{
Seija Jaakkola, Marketta Rinne, Terttu Heikkilä, Vesa Toivonen ja Pekka Huhtanen \\ Helsingin yliopisto ja Maa- ja elintarviketalouden tutkimuskeskus
}

Lypsylehmillä tehdyssä tutkimuksessa verrattiin käymisasteeltaan erilaisia (maitohappo/sokeri -suhde erilainen) säilörehuja. Tavoitteena oli selvittää täydennysrehujen vaikutusmekanismeja ja mahdollisuuksia poistaa säilörehun ominaisuuksiin liittyviä maidontuotantoa rajoittavia ravitsemuksellisia tekijöitä. Täydennysrehuna oli pelkkä vilja-leikeseos tai siihen sisältyi valkuaisrehu (1,8 kg/d rypsirouhetta), pötsissä propionihappoa tuottava väkirehu (mukana $225 \mathrm{~g} / \mathrm{d}$ propyleeniglykolia) tai molemmat. Lisäksi rehujen vaikutusta pötsikäymiseen selvitettiin erillisessä kokeessa.

Säilörehun käymistä säädeltiin käyttämällä säilöntäaineena muurahaishappoa $(0,2,4$ tai $61 / t$ puhtaana happona, lyhenteet $\mathrm{FA}_{0}, \mathrm{FA}_{2}, \mathrm{FA}_{4}, \mathrm{FA}_{6}$ ). Happomäärää lisättäessä sokerin määrä säilörehussa lisääntyi, maitohapon määrä pieneni ja valkuaisen hajoaminen väheni. Koska raaka-aineen kuiva-ainepitoisuus oli melko korkea ja se sisälsi runsaasti sokeria, myös ilman säilöntähappoa tehty rehu oli melko puhtaan maitohappokäymisen vuoksi hyvälaatuista. Rehun käymisastetta kuvaavat sokeri- ja maitohappopitoisuudet muuttuivat säilöntähapon annostustason kasvaessa seuraavasti: sokeri 38, 60, 70 ja 119 $\mathrm{g} / \mathrm{kg}$ kuiva-ainetta (ka) sekä maitohappo 81, 64, 48 ja 21 $\mathrm{g} / \mathrm{kg}$ ka. Valkuaisen hajoamista kuvaava ammoniakkitypen osuus oli vastaavasti $84,51,60 \mathrm{ja} 43 \mathrm{~g} / \mathrm{kg} \mathrm{N}$.

Säilörehun käymisen rajoittaminen lisäsi maitotuotosta käyräviivaisesti. Paras tuotos saavutettiin $\mathrm{FA}_{6}$-rehulla, mutta $\mathrm{FA}_{2}$ oli parempi kuin $\mathrm{FA}_{4}$. Valkuaistuotos puolestaan lisääntyi lineaarisesti rajoitettaessa säilörehun käymistä. Maidon korkean rasvapitoisuuden yhteys säilörehun rajoittuneeseen käymiseen tuli esiin kokeessa. $\mathrm{FA}_{0}$-ruokinnalla todettu korkea rasvapitoisuus oli kuitenkin poikkeava tulos. Maidon valkuaispitoisuus oli suurin $\mathrm{FA}_{4}$-ruokinnalla, mutta erot säilörehujen välillä olivat melko pieniä.

Säilörehujen ja väkirehujen välillä todettiin yhdysvaikutuksia. Tämän perusteella täydennysrehujen vaikutus voi vaihdella eli käymisasteeltaan erilaisten säilörehujen ravitsemukselliset puutteet ovat erilaisia. Propyleeniglykoli paransi maitotuotosta rajoittuneesti käyneiden rehujen täydentäjänä. Tulos tukee hypoteesia, jonka mukaan rajoittuneesti käynyttä rehua syötettäessä glukoosi voi olla tuotantoa rajoittava tekijä. Propyleeniglykolin rasvapitoisuutta pienentävä vaikutus oli selvä kaikkia säilörehuja täydennettäessä. Myös valkuaislisä paransi maito- ja valkuaistuotosta säilörehun koostumuksesta riippumatta. Vaikutukset maidon rasva- ja valkuaispitoisuuksiin sen sijaan vaihtelivat eri säilörehuja syötettäessä.

Säilörehun käymisen selkeä rajoittaminen suuren happomäärän $\left(\mathrm{FA}_{6}\right)$ avulla lisäsi lehmien maitotuotosta. Toisaalta myös kohtuullisesti maitohappokäyneellä rehulla $\left(\mathrm{FA}_{2}\right)$ saatiin hyvä maitotuotos. Tuotantotulosten perusteella käymisasteeltaan erilaisten säilörehujen täydennystarve on erilainen. 